\title{
Novinky v liečbe srdcového zlyhávania - editorial
}

\author{
Ján Murín \\ I. interná klinika LF UK a UNB, Nemocnica Staré mesto, Bratislava, Slovenská republika \\ Komentář k | Editorial on \\ Souček F et al. Novinky v léčbě srdečního selhání. Vnitř Lék 2017; 63(04): 255-264.
}

Srdcové zlyhávanie (SZ) je dnes velmi častým ochorením a jeho výskyt neustále stúpa, hlavne u starších (nad 65 rokov) l'udí - jednak pre predlžovanie veku, ale aj pre lepšiu liečbu iných kardiovaskulárnych ochorení (akútneho infarktu, akútneho SZ, chlopňových ochorení a d’alších stavov). Ochorenie sa diagnostikuje klinicky podla symptómov a prejavov, niekedy siahame po vyšetrení biomarkerom (BNP, NTproBNP), echokardiografické vyšetrenie je nutné jednak k zisteniu typu SZ (s redukovanou alebo zachovalou ejekčnou frakciou lavej komory), ale informuje nás aj o morfologických a funkčných pomeroch srdca (čo je významné z prognostického hladiska). Odhad prognózy je dôležitý aj z hladiska plánu liečebného prístupu (starší pacient v NYHA triede III-IV je spokojný so zlepšením kvality života, u iných možno zlepšit’ funkčnú zdatnost', bránit’ hospitalizáciám alebo možno uvažovat' aj o redukcii mortality). Užitočným prognostickým ukazovatelom je výpočet tzv. MAGGIC skóre, dostupný aj na webe a jednoducho kalkulovaný z údajov, ktoré sú obecne u pacienta so SZ vždy dostupné - navýšenie jedného bodu zvyšuje výskyt mortality/hospitalizácií pre SZ u chorého asi o $6 \%$ [1].

U SZ s redukovanou ejekčnou frakciou, tj. u systolického SZ, máme dostupnú jasnú liečbu, ktorá bola za posledných asi 20 rokov postupne otestovaná v mnohých klinických štúdiách. Preto sa tejto forme SZ venovali aj autori [2]. Správne predstavili nové liečivo SZ, tzv. ARNI (sakubitril/valsartan), ktorý podla štúdie PARADIGM HF [3] môže nahradit’ v liečbe ACE inhibítor, nakol'ko je o $20 \%$ účinnejším v redukcii kardiovaskulárnej mortality/rehospitalizácií pre SZ. Treba tu ešte upozornit’ na to, že pri užívaní biomarkeru ako vodítka posúdenia zlepšenia stavu chorého, sa má používat' NT-proBNP (pri zlepšení stavu chorého jeho hodnota v sére klesá) a nie BNP (jeho hodnota v sére stúpa, lebo sakubitril blokuje odbúravanie BNP, a preto BNP neinformuje o benefite liečby SZ) [4]. Aby sa minimalizovalo riziko výskytu angioedému, u chorého na liečbe ACE inhibítorom treba pred nasadením ARNI liečbu ACE inhibítora na 36 hod prerušit', a až potom ARNI nasadit'. Empagliflozín (štúdia EMPA-REG OURCOME, viac ako 7000 diabetikov 2. typu s vysokým kardiovaskulárnym rizikom) ohromne prekvapil redukciou kardiovaskulárnej mortality (o $38 \%$ ), redukciou hospitalizácií pre SZ (o $35 \%$ ), redukciou celko- vej mortality (o $32 \%$ ), ale neovplyvnil výskyt infarktov myokardu, a tak sa predpokladá, že ovplyvnil hlavne hemodynamiku a SZ (ved' je to vlastne osmotické diuretikum) $[5,6]$. Prebiehajú klinické štúdie s empagliflozínom a dapagliflozínom u pacientov so SZ, a nielen u diabetikov, ale aj u nediabetikov - výsledky možno očakávat’ asi za 3-4 roky. Môžeme predpokladat', že by to mohol byt' nádejný liek i pre SZ.

V oblasti farmakoterapie SZ so zachovalou ejekčnou frakciou nemáme jasné „odporúčania“, a tak volíme diuretiká pri prevodnení, liečbu komorbidít (predsieňovej fibrilácie, diabetu, sideropénie, obštrukčnej choroby plúc apod), ale siahame i po neurohormonálnej blokáde ako v prípade SZ s redukovanou ejekčnou frakciou.

Farmakoterapia akútneho SZ je dobre autormi rozobratá. O prognóze chorého často rozhoduje jednak príčinné ochorenie, napr. rozsah akútneho koronárneho syndrómu, ale významnú úlohu u systolického akútneho SZ hraje aj hodnota krvného tlaku pri prijatí. Ak je tlak vysoký, máme viac priestoru pre úspešnú liečbu a prognóza chorého býva tiež lepšia. Ak je však chorý hypotenzný, jeho prognóza dobrá nebýva, ale týchto chorých v reálnej praxi býva naštastie menej, asi 5-10\% [7].

Prístrojová (non-farmakologická) liečba je tiež dobre rozobratá. Môžeme konštatovat', že liečebné prístupy k chorým s chronickým systolickým SZ sa predsa len zlepšili. Výskumné úsilie si dnes vyžaduje hlavne SZ so zachovalou ejekčnou frakciou. Zdá sa, že u týchto pacientov jestvuje viac rôznych fenotypov ochorenia, napr. hypertenzívny fenotyp (s hypertrofiou lavej komory), diabetický fenotyp SZ, amyloidový fenotyp apod - a je možné, že im treba priradit’ rozdielny liečebný prístup, zatial'však sú to skôr hypotetické úvahy.

Hlavné klinické úsilie u SZ by malo byt' dnes hlavne $v$ prevencii ochorenia, teda v lepšej a skoršej liečbe hypertenzie a iných rizikových faktorov (diabetes, obezita, dyslipidémia) a aj ochorení (ischemická choroba srdca), d’alej v prevencii fajčenia a vo zvyšovaní telesnej aktivity občanov. U rizikovejších pacientov môžeme objavit' prítomnost' SZ napr. vyšetrením už spomínaných biomarkerov v sére (BNP, NT-proBNP) s nádejou, že pri skoršom zistení ochorenia uspejeme skoršou liečbou SZ. V oblasti akútneho SZ sa uvažuje o podobnom prístupe 
$\mathrm{k}$ tomuto ochoreniu, ako je to s akútnymi koronárnymi syndrómami - tj. vyhladat' pacientov čím skôr a čím skôr zhodnotit klinický stav a jeho príčinu a hlavne čím skôr im zabezpečit' liečbu.

\section{Literatúra}

1. Pocock SJ, Ariti AC, McMurray JJV et al. Predicting survival in heart failure: a risk score based on 39372 patients from 30 studies. Eur Heart J 2013; 34(19): 1404-1413. Dostupné z DOI: <http://dx.doi.org/10.1093/ eurheartj/ehs337>.

2. Souček F, Novák J. Novinky v léčbě srdečního selhání. Vnitř Lék 2017; 63(4): 255-264.

3. McMurray JJV, Packer M, Desain AS et al. Angiotensin-neprilysin inhibition versus enalapril in heart failure. NEngl J Med 2014; 371(11): 9931004. Dostupné z DOI: <http://dx.doi.org/10.1056/NEJMoa1409077>.

4. Zile MR, Claggett $B L$, Prescott MF et al. Prognostic implications of changes in N-terminal pro-B-type natriuretic peptide patients with heart failure. J Am Coll Cardiol 2016; 68(22): 2425-2436. Dostupné z DOI: <http://dx.doi.org/10.1016/j.jacc.2016.09.931>.
5. Zinman B, Wanner C, Lachin JM et al. [EMPA-REG OUTCOME Investigators].Empagliflozin, cardiovascular outcomes, and mortality in type 2 diabetes. N Engl J Med 2015; 373(22): 2117-2128. Dostupné z DOI: <http://dx.doi.org/10.1056/NEJMoa1504720>.

6. Murín J. Empagliflozín (inhibítor sodíkovo-glukózového kotransportéra 2) - nádej pre diabetikov 2. typu. Cardiol Lett 2016; 25(1): 45-48.

7. Nohria A, Tsang SW, Fang JC et al. Clinical assessment identifies hemodynamic profiles that predict outcomes in patients admitted with heart failure. J Am Coll Cardiol 2003; 41(10): 1797-1804.

\section{prof. MUDr. Ján Murín, CSc. \jan.murin@gmail.com}

I. interná klinika LF UK a UNB, Nemocnica Staré Mesto, Bratislava, Slovenská republika

www.unb.sk

Doručeno do redakce 9. 3. 2017 